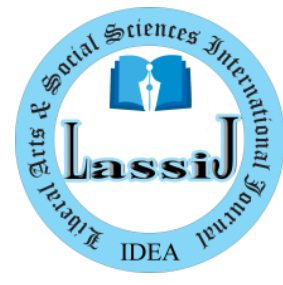

Research Article

ISSN: 2664-8148 (Online)

Liberal Arts and Social Sciences

International Journal (LASSIJ)

https: / / doi.org/10.47264/idea.lassij/3.2.7

Vol. 3, No. 2, (July-December) 2019, 59-64

https://www.ideapublishers.org/lassij

\title{
Impact of Stress on the Performance of University Students in the Light of Krashen's Affective Filter Theory
}

\author{
Bakht Rahman*1-2, Salman Hamid ${ }^{2}$ and Asma Gul ${ }^{3}$ \\ 1. Department of English, University of Wah, Wah Cantonment, Pakistan. \\ 2. Department of English, Qurtuba University Peshawar, Peshawar Pakistan. \\ 3. Department of Education, International Islamic University, Islamabad, Pakistan.
}

Received: June 19, 2019

Published Online: May 15, 2020

\begin{abstract}
This paper investigates the impact of stress on the performance of students in the light of Krashen's affective filter theory. Stress, according to Krashen, is responsible for high affective filter which in turn is responsible for low input and as a result, poor performance of the students in terms of language acquisition. Stress is, therefore, a key factor in affecting the academic performance of students at various levels. Students are often under pressure either on the part of their parents, colleagues or from their teachers to secure good grades. There are certain other variables too which contribute to the stress level of students and thereby affect their language acquisition. This quantitative study uses a questionnaire to collect data from 90 students of $1^{\text {st }}$ semester in Women University Swabi. The background of the students was from social and applied sciences where the students study this as compulsory course. The results of the data show that stress has a definite negative impact on the performance of students. The study has important implications for educationists, academics, and policy makers.
\end{abstract}

Keywords: students stress, impact of stress, performance of students, language acquisition

\section{Introduction}

Stress has been known to have a significant impact on the lives of people in general and on students in particular. A variety of factors have been associated with stress among students. These include problems with peers, environment factors, family, and financial status, to name a few. Apart from these, academic pressure has also been identified as a major reason for causing stress among the students. In a classroom environment, stress plays a significant role and the purpose of this paper is to highlight the negative impact of stress on the performance of students in terms of language acquisition. If the students are under duress, their performance in the target language might not be up to the mark. At academic level, stress creates difficulties in learning/acquisition of second language.

Stephen Krashen (1982) highlighted the role of anxiety/stress in his Affective Filter Theory. He presented the idea of Monitor Model which includes five hypotheses. The concept of 
Affective Filter Theory is based on the idea that if a student has not received enough comprehensible input, their learning will be affected. Affect, according to Krashen, refers to factors including motivation, attitude, self-confidence, or anxiety (stress). Krashen, therefore, suggests an affective filter, which is actually the level of anxiety or stress. If the filter is up, due to stress, it will prevent the input from passing through; as a result, there can be no acquisition. If, conversely, the filter is low or down, which means a low or no stress, and if the input is comprehensible, it will reach the acquisition device, which according to Krashen represents the mind, and acquisition will take place.

The Affective Filter Theory, presented by Krashen, has four components: motivation, attitude, self-confidence, and anxiety or stress. Keeping in view the Affective Filter Theory, the present research is aimed to explore whether stress has a negative impact on the achievement of BS level students, who studied English as a compulsory course, at a Women University Swabi. The research question around which this study revolve was: what is the impact of stress on the performance of university students in the light of Krashen's Affective Filter Theory.

\section{Review of Literature}

The Affective Filter Theory was proposed by Dulay and Burt in 1870s. Later, Krashen (1981) worked on it and devised a Monitor Model comprising of five hypotheses: The Acquisitionlearning Distinction; the Natural Order Hypothesis; the Monitor Hypothesis; the Input Hypothesis, and the Affective Filter Theory. Affective Filter creates obstacles for language learners, and they cannot absorb comprehensible input completely. The affective filter consists of variables such as leaners' attitude to language, motivation, self-confidence, anxiety and so on and so forth. The learners who have a low filter may have favourable attitudes to learning and self-confidence. Learners having high filters can have adverse attitudes and high level of anxiety and stress which may result in low comprehensible input. If students are under stress, they may not be able to assimilate what the teacher is trying to convey, that is, the input. It, therefore, affects acquisition and learning.

The Affective Filter Theory asserts that learners will benefit from comprehensible input if they are feeling happy and secure. On the other hand, if the students are not satisfied with the learning environment, their progress may be low even though the teacher provides rich comprehensible input. The input is an important aspect of learning which depends on the filter level of the students. If the students are not at ease, and if they are under stressed for any reason, the filter will be high according to Krashen. As a result, learning will not effectively taking place. The teacher's role is therefore extremely important since he is not only teaching but also motivating the students to take interest in what is going on in the classroom situation. Therefore, the lowering of filter is important for effective acquisition of language. Certain strategies of the ESL are generally based on two hypotheses presented by Krashen about second language acquisition (Krashen, 1981, 1982, 1983, 1985, \& 1987): (a) the Input Hypothesis, and (b) the Affective Filter Theory.

The role of Krashen's Affective Filter Theory is significant in the teaching and acquisition of second language (Wenjuan Wang (2013) analysed the role of affective factors such as motivation, attitude, and Chinese cultural characteristics and their impact on the acquisition of Chinese language. This study shows that motivation and attitude are interrelated and the later affects the former. The researcher has highlighted the role played by attitude in motivating the students where it helped in comprehensible input. Comprehensible input can be effectively 
carried out only when the students are highly motivated. This study therefore highlights the significance and role of motivation and attitude towards language learning in the Chinese cultural backdrop. It has concluded that both these factors have significance influence on the learning behaviour of the students.

Swanson (2013) explored the impact of teachers 'sense of humour on the acquisition of second language. He asserts that it is directly related to a lot of outcomes both for teachers as well as students. Swanson used Affective Filter Theory as a conceptual framework, and highlighted the correlation between the supposed sense of humour of Spanish teachers $(n=102)$ and their students' $(n=5,419)$ results in the National Spanish exam and found that teachers' sense of humour has a negative impact on the achievements of the students in their exams.

Similarly, Mangubhai (2001) found that not only the comprehensive input is important but also the way this input is provided to the students i.e. the form or style. In this connection, he cites the Fiji Book Flood which not only provides conducive environment for comprehensible input but also the procedure of how to effectively transmit this comprehensible input. The Fiji Book Flood was one of the studies (2001) regarding the significance of input in term of comprehensive reading at different levels particularly Grad 4 and 5 in relation to the controlled groups. The finding of this research shows that a good and regular reading practice has contributed to proficiency in reading and listening in the second language as compared to the control groups among the students of Grades 4 and 5. Reading served as a motivational element for the students and the results have shown the efficacy of the strategy employed.

Rodrigoa, Krashen, \& Gribbons (2004) suggested that a person acquires a language when he/she understands what he/she hears and what he/she reads. It is in this context that the current research explored whether there is any relation between stress and the performance of students or not. The current research investigated possible relationship between stress and learning of second language among the BS students of first semester at Women University, Swabi in Khyber Pakhtunkhwa, Pakistan.

\section{Materials and Methods}

This study adopted quantitative, and descriptive research design. The population of the study consisted of students of BS $1^{\text {st }}$ semester, where the researcher was teaching the course, at a university in Swabi, Khyber Pakhtunkhwa, Pakistan. The sample consisted of 90 students. Data was collected from the sample using a questionnaire because the number of students was large and interviews were not possible for gathering data. In addition to that some students were reluctant and were not in support of the interview. Questionnaires were filled in and their names were not compulsory for their feedback. So the students, since they were all female, give their feedback without any pressure. The questionnaires were administered in the classrooms and the purpose of collecting the information was conveyed to the students. Their identity was not revealed so that they could freely share what they thought and felt about the issue under consideration. The questions were related to the reasons of stress and how the students cope with stress. The data was collected through questionnaires and was analysed through SPSS.

\section{Results and Discussion}

Table- 1 shows the questions and the responses from the students. Copies of the questionnaires were distributed among 90 students; however, some respondents did not give response to some 
of the questions. Consequently, the number of responses to various questions vary. Table-1 shows that $50 \%$ of the students were under stress due to their studieswhereas $14 \%$ faced stress due to their parents. Around $14 \%$ were under stress due to parental and peer pressure and another $14 \%$ due to the fear of failure.

Excessive stress resulted in poor performance in academics and as a result led to their drop out. Table- 1 also shows that one of the major reasons for stress was a focus on achieving higher grades as $70 \%$ of the students reported. The students, during this time, that is during their semester, all were after securing the grades. Now this mad competition resulted in some kind of mental pressure that they have started suffering from. Ultimately, the overall impact of these variables was that students suffered mentally and, due to this, their affective filter went high. According to Krashen, if the filter is up, the performance of the students will be low. As a result, the students cannot receive proper input which ultimately affects their performance in their academic achievement. Krashen is of the view that for better understanding and good academic performance, the affective filter must be lower so that proper input, reception of innovative ideas, could take place. Only after such an input, the performance of students can be improved.

The results of parental pressure statement show that the students faced pressure in their academic career. Parents are considered a key factor in the mental development of their children; however, parents did not seem to be coming up to the expectations of the students. The results showed that $61 \%$ students considered their parents responsible for their stress. The reason may be that the parents may be having high expectations from their children only in terms of marks and grades whereas education is a holistic process, and majority of the parents do not understand this fact. If the parents could help their kids by not expecting only high grades all the time, students 'affective filter may remain low, and the input maybe much greater as compared to a high level of affective filter.

The next question was related to peer pressure which came out as a very important variable contributing to raising the affective filter of the students. Peer pressure has always influenced the behaviour of s student in terms of language acquisition. As the students wanted to compete for grades, it definitely affected their learning. Data shows whether peer pressure can also contribute to the stress level of the students. Majority of the students were of the opinion that peer pressure has an impact on their performance.

The Table also indicates that $37 \%$ students felt pressure and stressed due to increased number of classes per week. Another $29 \%$ were scared of quizzes, assignments, and examinations thereby coming under stress. Therefore, they find less time for their studies. In addition to that many of them were unable to find out some free time for their recreational activities which are of course part and parcel of education. Due to this tough and busy schedule that they had during the semester, they were unable to find out some sources of recreation which could possibly help him in reducing their stress and thereby lowering their filter down. As a result, too many classes, quizzes and assignments also influence their performance in their academic career. In addition, the teacher role is also of paramount significance in this regard. A lot of teachers take so many quizzes and assignments all the time which results in burden on the students. The teachers are also expecting extraordinary performance from the students while many at times ignoring their demand and requirement; the students become anxious which results in stress. Thus, the affective filter goes high and a low input takes place. In such situation, the students would not be in a better position to absorb what the teacher is trying to convey to them. 
The final question was related how to lower down the level of stress among the students. It is imperative for the students to lower down their affective filter for better input. Different students use different strategies to lower down their affective filter. This Table shows the stress relieving factors, and most of the students i.e. 34\% are listening to music to reduce their stress level thereby bringing down the affective filter. Sometimes, they are involved in recreational activities such as music, sports, swimming, or painting. Emotionally, students get tired and at the same time having sleep deficit as well. As a result, their affective filter is down, and the input becomes effective. This results in better understanding of the input which affects their performance.

In this questionnaire, the researcher has investigated only one factor of the Affective Filter Theory i.e. stress. It is one of the four components of the hypothesis which, according to Krashen, contributes to the acquisition of language. In all these questions in the table, the researcher has analysed the impact of stress on the performance of the students.

Table-1

\begin{tabular}{|c|c|c|c|c|c|c|}
\hline No. & Questions & Perceptions & Grades & $\begin{array}{l}\text { Parental } \\
\text { Pressure }\end{array}$ & $\begin{array}{c}\text { Peer } \\
\text { Pressure }\end{array}$ & Failure \\
\hline \multirow{2}{*}{1} & \multirow{2}{*}{$\begin{array}{l}\text { What is the main reason for } \\
\text { stress in your academic } \\
\text { life? }\end{array}$} & OV & 42 & 12 & 12 & 18 \\
\hline & & $\% \mathrm{~V}$ & $52 \%$ & $14 \%$ & $14 \%$ & $22 \%$ \\
\hline & & & \multicolumn{2}{|c|}{ Yes } & \multicolumn{2}{|c|}{ No } \\
\hline \multirow{2}{*}{2} & \multirow{2}{*}{$\begin{array}{l}\text { Do you think parents are } \\
\text { responsible for your stress? }\end{array}$} & OV & \multicolumn{2}{|c|}{20} & \multicolumn{2}{|c|}{40} \\
\hline & & $\% \mathrm{~V}$ & \multicolumn{2}{|c|}{$11 \%$} & \multicolumn{2}{|c|}{$28 \%$} \\
\hline \multirow{2}{*}{3} & \multirow{2}{*}{$\begin{array}{l}\text { Do you think peer pressure } \\
\text { is also one of the major } \\
\text { factors for your stress? }\end{array}$} & OV & \multicolumn{2}{|c|}{35} & \multicolumn{2}{|c|}{20} \\
\hline & & $\% \mathrm{~V}$ & \multicolumn{2}{|c|}{$39 \%$} & \multicolumn{2}{|c|}{$22 \%$} \\
\hline & & & $\begin{array}{l}\text { Increased } \\
\text { Classes }\end{array}$ & \multicolumn{2}{|c|}{$\begin{array}{c}\text { Increased Work } \\
\text { Hours }\end{array}$} & Exams \\
\hline \multirow{2}{*}{4} & \multirow{2}{*}{$\begin{array}{l}\text { What are the academic } \\
\text { factors for stress? }\end{array}$} & $\mathrm{OV}$ & 33 & \multicolumn{2}{|c|}{20} & 26 \\
\hline & & $\% \mathrm{~V}$ & $37 \%$ & \multicolumn{2}{|c|}{$22 \%$} & $29 \%$ \\
\hline & & & $\begin{array}{l}\text { Listening } \\
\text { to music }\end{array}$ & Eating & Exercise & Meditation \\
\hline \multirow{2}{*}{5} & \multirow{2}{*}{$\begin{array}{l}\text { What do you do to relieve } \\
\text { your stress? }\end{array}$} & $\mathrm{OV}$ & 31 & 22 & 24 & 13 \\
\hline & & $\% \mathrm{~V}$ & $34 \%$ & $24 \%$ & $27 \%$ & $15 \%$ \\
\hline
\end{tabular}

Note: $O V$ represents object value and \%V represents percent value.

\section{Conclusion}

The analysis of the data proves that stress contributes to the poor performance of the students. The positive stress can sharpen the mind, intellect, and reflexes of the individuals. When a student feels high level of chronic stress, irrespective of her age or grade, it can interfere with her ability to memorize, learn, and earn good grades. All these factors, discussed in detail in the discussion and analysis part of this study, bring up the affective filter of the students and as a result, they are not getting the comprehensive input which certainly affects their language learning or acquisition. Therefore, according to Krashen, if the filter is up, the language imparted would be having no significance. The research has investigated some of the factors 
only to assess that stress has a definite impact on the language acquisition of students. Almost all the factors discussed in this research contribute to high level of affective filter which ultimately affects the input provided by the teachers. The evidence for this claim has been highlighted by the data gathered from the students of BS $1^{\text {st }}$ where they were studying the course as university requirements. After evaluating the factors through SPSS, the finding of the study also prove that affective filter plays an important role in the acquisition of language. If the filter is down, which means the students are relaxed and not under any kind of stress, the input will reach the device, which is understanding; if, on the other hand, the filter is up, which means the students are under stress, the input will not take place, and as a result, the understanding of the students would be poor.

\section{References}

Mangubhai, F. (2001). Book floods and comprehensible input floods: Providing ideal conditions for second language acquisition. International Journal of Educational Research, 35, 147-156. Retrieved from https://doi.org/10.1016/S0883$\underline{0355(01) 00012-\mathrm{X}}$

Shaikh, B. T., Kahloon, A., Kazmi, M., Khalid, H., Nawaz, K., Khan, N., Khan, S. (2004). Students, stress, and coping strategies: A case of Pakistani medical school. Education Health (Abingdon), 17(3), 346-353. Retrieved from https://doi.org/10.1080/13576280400002585

Shields, N. (2001). Stress, active coping, and academic performance among persisting and nonpersisting college students. Journal of Applied Bio behavioural Research, 6(2), 65-81.

Smith, M., Jaffe-Gill, E., Segal, J., \& Segal, R. (2007). Preventing Burnout. Signs, symptoms, and strategies to avoid it. Retrieved from http://www.helpguide.org/mental/burnout_signs_symptoms.htm

Ross, S. E., Niebling, B. C., \& Hecker, T. M. (1999). Sources of stress among college students. College student Journal, 33, 312-314.

Krashen, S. D. (1982). Principles and Practice in Second Language Acquisition. The University of Michigan Pergamon.

Supe, A. (1998). A study of stress in medical students at Seth G.S. Medical College. Journal of Postgraduate Medicine, 44(1), 1-6.

Swanson, P. B. (2011). Spanish Teachers' Sense of Humour and Student Performance on the National Spanish Exams. Foreign Language Annals, 46(2), 146-156. Retrieved from https://scholarworks.gsu.edu/mcl_facpub/20

Rodrigo, V., Krashen, S., \& Gribbons, B. (2004). The effectiveness of two comprehensibleinput approaches to foreign language instruction at the intermediate level. System, 32, 53-60. https://doi.org/10.1016/j.system.2003.08.003

Wang, W. (2013). Research on the Influence of Affective Factors to Ethnic Chinese Student's Chinese Acquisition: Take the Ethnic Chinese Students in Fiji as an Example. Canadian Social Science, 9(3), 57-60. Retrieved from https://doi.org/10.3968/j.css.1923669720130903.5746

Fang, X. U. (2010). The role of input and interaction in second language acquisition. CrossCultural Communication, 6(1), 11-17. Retrieved from https://citeseerx.ist.psu.edu/viewdoc/download?doi=10.1.1.878.4082\&rep=rep1\&ty pe=pdf 